\title{
EFQM EXCELLENCE MODEL AS THE TQM MODEL OF THE CONSTRUCTION INDUSTRY OF SOUTHEASTERN EUROPE
}

\author{
Mladen VUKOMANOVIC, Mladen RADUJKOVIC, Maja Marija NAHOD \\ Faculty of Civil Engineering, University of Zagreb, Kačićeva 26, HR-10002 Zagreb, Croatia
}

Received 21 Sep 2012; accepted 13 Nov 2012

\begin{abstract}
Over the years the European Foundation for Quality Management Excellence model (EFQM) has become a popular performance management tool and representation of Total Quality Management (TQM) in Europe. Although the model has been tested and supported by many questionnaire surveys, EFQM has never been validated on real selfassessment scores obtained from companies. Therefore this study validates the model on scores from 34 construction companies in South Eastern Europe. The analysis shows that: a) there is an enabler excellence construct that is obtained by each enabler criteria; b) there is a result excellence construct that is obtained by each result criteria; and c) the EFQM model is most suitable for Contractor type organizations. Furthermore, we have found that the EFQM weights do not entirely correspond with the construction industry. Therefore we present new weights for the better use in the construction. Although this study proves EFQM to be a good representation of TQM in the construction industry, further improvements are needed. This is especially evident within investor and consultant type organization, where the criteria of Policy and Strategy, Leadership and Processes, People results and Client results showed certain limitations.
\end{abstract}

Keywords: EFQM excellence model, validation, total quality management, factor analysis, the construction industry.

Reference to this paper should be made as follows: Vukomanovic, M.; Radujkovic, M.; Nahod, M. M. 2014. EFQM excellence model as the TQM model of the construction industry of southeastern Europe, Journal of Civil Engineering and Management 20(1): 70-81. http://dx.doi.org/10.3846/13923730.2013.843582

\section{Introduction}

The European Foundation for Quality Management Excellence model (EFQM) has become a very popular tool for not only assessing organizational performance, i.e. business excellence, but as an operational framework for implementing Total Quality Management (TQM) (Curkovic et al. 2000; Yong, Wilkinson 2001; Lee et al. 2003; Bassioni et al. 2004, 2005). Past studies show that regular use of performance management (PMM) models, i.e. the EFQM Excellence model (EFQM), positively influences business results (Qureshi et al. 2009; de Leeuw, van den Berg 2011; Bayo-Moriones, Merino-Díaz de Cerio 2001), especially in encouraging continuous improvement through self-assessment and benchmarking (Niven 2006). However, EFQM has also been criticized for not having a stronger link with strategy of the company and strategic integration process (Junnonen 1998). Despite the popularity of PMM models (of which the most popular ones are: EFQM, the Malcolm Baldridge National Quality Award and the Deming Prize), more than half fail (Bourne et al. 2003; Corredor, Go 2011). Regardless of its weak performance, EFQM has still become a renowned and untouched representation of TQM in Europe (Van der Wiele et al. 2000; Bayo-Moriones et al. 2011).
For example, International Project Management Association (IPMA) propagates The Project Excellence Model for assessing project management quality, which actually relies on EFQM and TQM principles (Westerveld 2003).

TQM has traditionally been connected with issues arising from construction, e.g. an extremely complex combined process, production flow, various structures, high quality requirements and long construction cycle (Tchidi et al. 2012). The reason for this may be found in the industry's contrasts with manufacturing, where TQM first originated (Ahmad, Sein 1997; Stockdale 1998). However, unlike TQM, EFQM is a prescriptive model, well defined and easily understood by construction companies (Watson, Seng 2002). Still, the model has never been validated on the EFQM self-assessment scores (Bou-Llusar et al. 2009), except limited to Curkovic et al. (2000), but only tested on results obtained from questionnaire surveys, where project management professionals gave their perceptions regarding use of EFQM (Bou-Llusar et al. 2009; Tari et al. 2007). Furthermore, there is scarcity of studies that validate quality award models in general (McAdam, Leonard 2005). This raises concerns whether EFQM is a valid quality management model for the construction industry.

Corresponding author: Mladen Vukomanovic

E-mail:mvukoman@grad.hr 
Therefore, the objective of this study is to analyse and validate the use of EFQM and attempt to improve methodological rigor in analysing quality in the construction industry. To validate the model we will use data gathered from 34 EFQM self-assessment scores of 34 construction companies in South Eastern Europe (i.e. Bosnia and Herzegovina, and Croatia). Afterwards we will calculate a correlation matrix of EFQM criteria and compare the scores with the original theoretical presumptions of the model. Furthermore we will conduct a factor analysis to test the structure within the two types of EFQM criteria: Enablers and Results, and thus obtain an overall interpretation of the ratio correlations. At the end we will propose new weights for EFQM's use in the construction industry and give recommendations for the model's further improvements.

The paper is structured as follows: in the next section we will present a literature review, covering the relationship between EFQM and TQM, and give a brief overview of the performance management (PMM) discipline. Based on the literature review, in the Section 1, we will explain the research methodology. Section 2 will give the research hypotheses and explain their justification. Section 3 will describe the research methods used to test the hypotheses, and present the results. Section 5 will bring the main findings with a discussion of implications stemming from this research. Last section will give our conclusions and guidelines for further research.

\section{Literature review}

\subsection{EFQM Excellence Model (EFQM)}

EFQM was originally developed as a quality management system in 1991 (Hillman 1994) by the European Foundation for Quality Management (now known as just EFQM). The model is based on TQM principles and has recently been advocated by many authors (e.g. de Waal 2008; El-Mashaleh et al. 2007; EFQM 2005; Radujkovic et al. 2010). The main purpose of EFQM is to assess a company's business excellence by identifying deviations of performance from best practice, and generating a stimulus in the form of improving activities (Beatham et al. 2004). EFQM thus assesses performance through nine weighted criteria (Fig. 1) and their respective 32 sub-criteria. The model recognizes the distinction between leading indicators (Enablers) and lagging indicators (Results). The model starts with Leadership (a weight of 100 - see Fig. 1) which afterwards leads to the other 8 criteria. Client results (i.e. satisfying client needs) have the highest impact on the final score ( $20 \%$ or 200 points), which shows strong affiliation of the model to TQM principles. EFQM has become a very popular PMM tool in the construction industry (more than $60 \%$ of companies have implemented it (Andersen et al. 2000; Robinson et al. 2004)).

EFQM is a prescriptive model, based on a static design (just the opposite of many descriptive PMM frame-

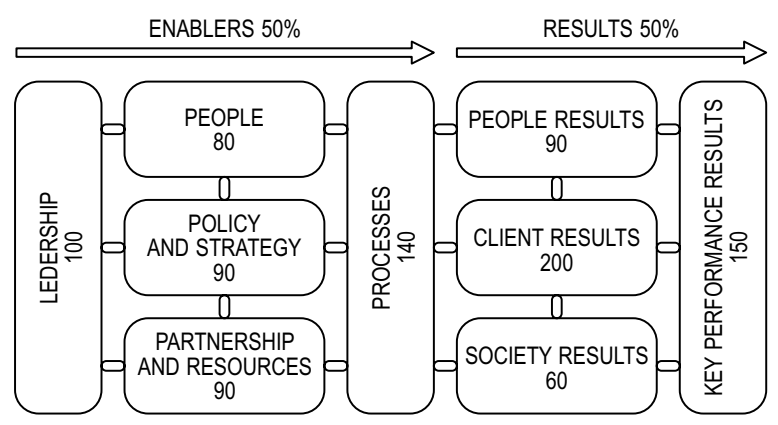

Fig. 1. EFQM Excellence model

works, such as: BSC (Kaplan, Norton 1992), Performance Prism (Neely 2002), Performance Measurement Matrix (Kennerley, Neely 2002), etc.) and consists of a pre-set of standards and a well-prescribed methodology of self-assessment. Therefore, companies find EFQM much easier to use than the other descriptive models (Robinson et al. 2004). EFQM maintains a relationship with the environment and can signalize which business processes are (or not) aligned with changes in the competitive environment.

The first major research in Europe about EFQM was conducted by Van der Wiele et al. (2000) where they reported on research work in Europe. Six European universities cooperated to conduct research into TQM and quality awards. Ritchie and Dale (2000) later found three groups of benefits that come from EFQM and the self-assessment process: 1. Immediate: benefits facilitates benchmarking, continuous improvement, encourages employee involvement and ownership, provides visibility in direction, raises understanding and awareness of quality related issues, develops a common approach to improvement across the company, seen as the marketing strategy, raising the profile of the organizations; 2. Long-term benefits: keeps costs down, improves business results, balances short term and long-term investments, develops a holistic approach to quality, maintains quality image, provides a link between customers and suppliers; Benefits of supporting TQM: focuses employees on quality, provides health check of processes and operations, focuses on processes and not just on the end product, encourages improvement in performance.

The evidence also suggests that the greatest impact on performance occurs about a year from receiving external recognition of implementing a quality award system (e.g. EFQM represents a long term process - the award can only come two years after the firm has totally implemented the system (Corredor, Go 2011)). However, the model has also received a great deal of criticism (Andersen et al. 2000; Codling 1995; Lam et al. 2004; McCabe 2001; Sharif 2002), mainly for its inability to focus and connect with firm's strategy (Rusjan 2005) and weak causal relationship between consequences and causes in business processes. 


\subsection{TQM in relation with EFQM}

Over the years different definitions of TQM have emerged. The literature review showed no unanimous definition of TQM, where the authors (Sila, Ebrahimpour 2002; EFQM 2005) have different views in defining TQM. Nevertheless experts (Bou-Llusar et al. 2009) agree that TQM is a management approach that relies on core concepts and principles that embody the way an organization is expected to operate, which will then consequently lead to a high level of performance. Furthermore, there is a general agreement that there has to be one general framework to put TQM into practice, even though there is presently no such general model in place (Yusof, Aspinwall 2000). We found many different approaches and standardized frameworks of implementing TQM (Deming 1982; Crosby 1979; Gryna, Juran 2001; Askey, Dale 1994; Tummala, Tang 1996; Kartha 2004), among which many authors support the thesis that quality award models (e.g. EFQM) fit the definition of TQM and represent a valid framework for TQM.

However, many of these initiatives have not been empirically tested. Thus the studies that focused on the internal structure of the award models (e.g. the appropriateness of certain sub criteria) did not try to establish whether the results produce high performance, i.e. looking at the bigger picture (Ahire et al. 1996; Grandzol, Gershon 1998). Eskildsen and Dahlgaard (2000) suggested a different linkage between the five enabler criteria; Prabhu et al. (2000) described three partial linkages of People and People Results, Leadership and Customer Results; Eskildsen et al. (2000) found how leadership affects People, Policy and Strategy criteria and Partnership and Resources affect Processes criteria; Reiner (2002) analysed EFQM's sibling in Australia and found direct dependence between the criteria; Bou-Llusar et al. (2009) found that EFQM Enablers improve performance in general; Calvo-Mora et al. (2005) focused on the inter-relationship among the criteria and found positive linkages among the majority of the criteria. After summing up the past work it is evident that even though EFQM is widely accepted as the European initiative of TQM, there are no studies that address this question empirically (Bou-Llusar et al. 2009; Nudurupati et al. 2010; Adair et al. 2003). Furthermore, over the past number of years the attitude towards TQM has become negative, where people misunderstand the concept and perceive it to be too technical. Thus it has gradually developed it into something different, known as Business Excellence (Ritchie, Dale 2000).

\section{Research hypotheses}

At the time of EFQM's birth, companies in Europe were paying attention to another management quality system: the ISO 9000 series of standards. Literature also indicates that workers care about the quality of their work and company's performance and that these aspects affect significantly their job satisfaction (Marzuki et al. 2012). Although these standards were initially developed as quality assurance systems, they were later changed to converge towards quality management system. Europe has given great importance to these standards, which have now become simply a requirement to do business in some sectors of Europe (Gomez et al. 2011). As EFQM is considered synonymous with TQM by many researchers (Adams et al. 1999; Forza, Filippini 1998; Rungtusanatham et al. 2005; Hendricks, Singhal 1996) and a logical step forward ISO 9000 certification, logical question would be whether EFQM is applicable to certain industries, in this case the construction.

The literature review showed how until now there have been no empirical studies (that relied on real EFQM scores, except Gomez et al. (2011)) and that have tested whether EFQM's criteria contribute to performance. Furthermore, all of the papers, except Bou-Llusar et al. (2009), study the EFQM model prior to version 2003. Therefore, this research was needed to validate the model's structure and to see whether all the criteria contribute to the same factors or do the Enablers and Results contribute separately. Hence our first hypothesis was: H1. Two categories, i.e. the Enablers and Results, are separately identifiable in the internal structure of the model and are presented as a latent factor that produces complementarities between their components.

Furthermore, the construction industry is a project-oriented industry which relies mostly on three management perspectives: investors (sponsors), consultants (project managers, developers, architects, designers, etc.) and contractors (sub-contractors). To test whether EFQM is applicable for every perspective, we divided our sample on the three perspectives. Therefore, our second hypothesis was: H2. The Excellence model is applicable for every management perspective in the construction industry.

And finally, we were interested in whether the weights correspond with the way that construction companies achieve excellence. If so, the relationship between the latent factor "excellence" and criteria would correspond with the original weights. In past studies, different authors (Eskildsen 1998; Eskildsen et al. 2000; Reiner 2002; Bou-Llusar et al. 2009; Calvo-Mora et al. 2005; Gomez et al. 2011) mainly focused on analysing the relationships of the EFQM model and not whether they really represent the performance. We only found Bassioni et al. (2008) to question the model's relationships, but again, the study was based on secondary data. Therefore, with our third hypothesis: H3. The original EFQM weights correspond with the way that construction companies achieve excellence; we wanted to see to what extent the model's original weights converge with the weights calculated by the real empirical data.

\section{Research methodology}

First we ran a literature review of past TQM and EFQM research and consequently defined our hypotheses. Second, the EFQM self-assessment procedure (EFQM 2005) was implemented for the construction industry of South 
Eastern Europe (Bosnia and Herzegovina, and Croatia) during a period of 1.5 years. Data was provided by the research team composed of authors of this paper and one consultancy agency that has been cooperating with EFQM in evaluating construction companies. All of the data acquired was kept confidential. There are five different techniques of assessing scores. Although there is a lack of literature on self-assessment methods we chose the Workshop Approach (EFQM 2005) since the method showed as a relatively objective method (Ritchie, Dale 2000). We ran the workshop method throughout five steps: 1 . The assessors are explaining the EFQM model; 2. The data is gathered on-site; 3. Representatives of an organization (form upper, middle and lover management levels), together with the research team, are gaining consensus over the scores for each factor; 4. Areas for improvement are being identified; 5 . Improvements are being assessed. The companies were chosen from database of Croatian Chamber of Chartered Engineers in Construction (HKIG 2012) industry, which covers all of the 142 medium-sized and large companies that operate in Croatia and Bosnia and Herzegovina. In total we covered 34 medium-sized (41.1\%) and large companies $(58.9 \%)$, which we had grouped in three management categories: investors $(20.5 \%)$, consultants $(29.5 \%)$ and contractors $(50.0 \%)$. After having looked at the construction industry from these three perspectives we were able to identify best practice and understanding how EFQM differs amongst different management perspectives. Third, the data collected were further analysed through reliability (Cronbach's alpha) and validity (Factor Analysis). The factor analysis assumed that all of the EFQM criteria contribute to a latent factor called "excellence". Fourth, we computed the weights of the model criteria by calculating regression coefficients between the criteria and the latent factor. Fifth, by focusing on the correlation coefficients among the EFQM criteria, we tested whether the present model fits the construction industry.

\section{Research methods and results}

Tables 1 and 2 show the main descriptive statistics, for the variables. It can be seen that highest variance (standard deviation) was noticed within Client results. Furthermore, since the data were collected from three different kinds of organizations/perspectives (investors, consultants and contractors), results are also shown for every perspective (Table 1). Again the same high variance of Client results can be noticed across the three perspectives (Table 1). In general, the investors had the highest score (Table 1, score 422.3), the contractors followed with the score of 367.7 ; while the consultants had the lowest score of 362.2 of the total performance score (1000 points).

After having obtained these results, an analysis of variance (ANOVA) was conducted to evaluate if these differences were statistically significant. Table 1 shows the results. As can be seen, statistically significant differences were not found for any of the data. To test the criteria of different excellence models and TQM frameworks, checking the validity and reliability of the variables (the criteria) has become an integral part of research in quality management studies (Wilson, Collier 2000; Brewerton, Millward 2001), whereas reliability is a necessary measure, but not a sufficient condition to validity (Cooper, Emory 1995).The data were analysed using SPSS 12.0 software. Reliability addresses the consistency of the results and is mostly measured by Cronbach's alpha (Bassioni et al. 2005). We used Cronbach's alpha and set the reliability threshold $(\alpha)$ at 0.6 for new scales (Flynn et al. 1994). Cronbach's alpha calculates the proportion of the variability in the scores that is the result of differences among the companies. The alphas were computed separately for each of the groups. Results in Table 3 show that all of the groups had favourable scores.

For testing construct validity (structure detection) we implemented Factor analysis, which shows the extent to which the items (the criteria) of a construct (the groups) measure the same construct (Flynn et al. 1994),

Table 1. Descriptives of the three perspectives and ANOVA to evaluate differences among the investors, consultants and contractors

\begin{tabular}{|c|c|c|c|c|c|c|c|c|c|c|c|c|c|c|c|}
\hline \multirow{2}{*}{$\begin{array}{l}\text { EFQM } \\
\text { criteria }\end{array}$} & \multicolumn{4}{|c|}{ Investors } & \multicolumn{4}{|c|}{ Consultants } & \multicolumn{4}{|c|}{ Contractors } & \multicolumn{3}{|c|}{ ANOVA - F statistics } \\
\hline & $\mathrm{N}$ & Max & StDev & Mean & $\mathrm{N}$ & Max & StDev & Mean & $\mathrm{N}$ & Max & StDev & Mean & Inv/Cons & Inv/Contr & Cons/Contr \\
\hline Lead. & 8 & 73 & 22.043 & 41.286 & 9 & 64 & 16.342 & 34.545 & 17 & 73 & 19.916 & 32.435 & 0.384 & 0.672 & 0.525 \\
\hline Strat. & 8 & 63 & 24.602 & 34.714 & 9 & 65 & 21.787 & 31.091 & 17 & 67 & 22.344 & 33.694 & 0.699 & 0.682 & 0.977 \\
\hline Peop. & 8 & 60 & 15.327 & 38.286 & 9 & 72 & 16.211 & 35.000 & 17 & 66 & 17.760 & 30.697 & 0.931 & 0.767 & 0.803 \\
\hline Partn. & 8 & 62 & 10.874 & 50.286 & 9 & 84 & 15.958 & 52.364 & 17 & 73 & 16.754 & 43.679 & 0.360 & 0.288 & 0.911 \\
\hline Process. & 8 & 116 & 38.598 & 79.857 & 9 & 117 & 29.716 & 71.273 & 17 & 116 & 35.729 & 68.048 & 0.443 & 0.725 & 0.558 \\
\hline Client_r & 8 & 158 & 56.668 & 67.571 & 9 & 125 & 38.777 & 50.091 & 17 & 134 & 43.511 & 42.119 & 0.276 & 0.348 & 0.729 \\
\hline People_r & 8 & 59 & 18.933 & 21.143 & 9 & 45 & 12.498 & 16.000 & 17 & 59 & 21.072 & 21.473 & 0.235 & 0.848 & 0.093 \\
\hline Society_r & 8 & 49 & 18.247 & 18.571 & 9 & 42 & 9.330 & 8.636 & 17 & 37 & 11.987 & 10.352 & 0.061 & 0.146 & 0.418 \\
\hline Key_r & 8 & 121 & 33.141 & 71.000 & 9 & 113 & 30.230 & 63.364 & 17 & 121 & 32.374 & 72.214 & 0.759 & 0.850 & 0.855 \\
\hline Mean of th & e to & scor & & 422.3 & & & & 362.2 & & & & 367.7 & & & \\
\hline
\end{tabular}


Table 2. Descriptives - all of the perspectives

\begin{tabular}{lcccc}
\hline & N & StDev & Mean & Max (out of 1000) \\
\hline Leadership & 43 & 18.263 & 32.974 & 73 \\
\hline Strategy & 43 & 21.646 & 32.351 & 63 \\
\hline People & 43 & 16.961 & 32.534 & 60 \\
\hline $\begin{array}{l}\text { Partnership \& } \\
\text { Resources }\end{array}$ & 43 & 16.496 & 46.614 & 62 \\
\hline Processes & 43 & 32.808 & 69.242 & 116 \\
\hline Clients & 43 & 45.337 & 48.288 & 158 \\
\hline People & 43 & 18.566 & 18.998 & 59 \\
\hline Society & 43 & 12.819 & 10.952 & 49 \\
\hline $\begin{array}{l}\text { Key performance } \\
\text { results }\end{array}$ & 43 & 31.041 & 68.773 & 121 \\
\hline
\end{tabular}

Table 3. Cronbach's alpha and 95 per cent confidence limits for each construct

\begin{tabular}{cccc}
\hline \multirow{2}{*}{$\begin{array}{c}\text { Cronbach's } \\
\text { Alpha }\end{array}$} & N of Items & \multicolumn{2}{c}{$95 \%$ Confidence Interval } \\
\cline { 3 - 4 } & Lower Bound & Upper Bound \\
\hline .893 & $\begin{array}{c}9 \text { (Enablers } \\
\text { and Results) }\end{array}$ & .829 & .939 \\
\hline .887 & 5 (Enablers) & .813 & .937 \\
\hline .699 & 4 (Results) & .491 & .836 \\
\hline
\end{tabular}

i.e. they do not measure multiple constructs (Cooper, Emory 1995). The purpose of the structure detection is to examine the underlying or latent relationships between the variables, in this case, three groups: enablers, results and all criteria together. The extraction method was Principal component analysis. The analysis assumed that some of the variability in the data cannot be explained by the components (called factors, in this case, the criteria). To interpret the results more easily we applied Varimax rotation. The communalities measure the percent of variance in a given variable explained by all the factors jointly and may be interpreted as the reliability of the indicator. If communalities are high (above 0.6 ) recovery of population factors in sample data is normally very good and almost regardless of: sample size, level of over determination or the presence of modal error (MacCallum et al. 2001). If the communality exceeds 1.0 , there is a spurious solution (too many or too few factors). Table 4 shows no spurious solutions. Still because the sample size, we double checked the data by calculating the subject to variable ratio (STV). STV for the enablers was 6.8:1 and for the results 8.5:1. This showed the sample size valid (Henson, Roberts 2006; Costello, Osborne 2005) and in accordance with current practice in factor analysis of construction management research $(87.09 \%$ studies had STV lower than 10:1 (Lingard, Rowlinson 2006)).

The Kaiser-Meyer-Olkin Measure of Sampling Adequacy indicates the proportion of variance in the variables that might be caused by underlying factors. High values (close to 1.0) indicate that a factor analysis may be useful and if the value is less than 0.50, the results will probably not be very useful. Bartlett's test of sphericity indicates that the variables are unrelated and therefore unsuitable for structure detection. Values of significance level less than 0.05 indicate that a factor analysis may be useful. Table 5 shows that all three constructs have a data set useful for factor analysis and suitable for structure detection.

Table 5. KMO and Bartlett's test of the three constructs

\begin{tabular}{lcccc}
\hline & Enablers & Results & All \\
\hline $\begin{array}{l}\text { Kaiser-Meyer-Olkin Measure } \\
\text { of Sampling Adequacy }\end{array}$ & .821 & .665 & .813 \\
\hline & $\begin{array}{l}\text { Approx. } \\
\text { Chi-Square }\end{array}$ & 117.821 & 44.056 & 226.559 \\
\cline { 2 - 5 } $\begin{array}{l}\text { Bartlett's Test } \\
\text { of Sphericity }\end{array}$ & df & 10.000 & 6.000 & 36.000 \\
\cline { 2 - 5 } & Sig. & .000 & .000 & .000 \\
\hline
\end{tabular}

Table 6 shows the factor analysis conducted on the enablers. As Table 6 suggests, only one factor was extracted (covering almost $75 \%$ of variance) with an Eigen value larger than 1 . Communalities in the right-hand column show that enablers contribute highly to one single construct that represents the enabler group.

Table 7 shows the factor analysis conducted on the Results. Just as with the Enablers, only one factor was extracted (covering almost $61.1 \%$ of variance) with an Eigen value larger than 1 . Communalities in the righthand column show that the results have a relatively high (not as much as the enabler group) contribution to one single construct that represents the whole result group.

Table 4. The communalities of the three constructs

\begin{tabular}{|c|c|c|c|c|c|c|c|c|}
\hline Enablers & Initial & Extraction & Results & Initial & Extraction & All & Initial & Extraction \\
\hline Lead. & .775 & .772 & Client_r & .454 & .457 & Lead. & 1.000 & .803 \\
\hline Strat. & .756 & .819 & People_r & .465 & .431 & Strat. & 1.000 & .878 \\
\hline Peop. & .723 & .685 & Society_r & .443 & .453 & Peop. & 1.000 & .721 \\
\hline Partn. & .565 & .592 & Key_r & .520 & .595 & Partn. & 1.000 & .642 \\
\hline \multirow[t]{5}{*}{ Process. } & .626 & .552 & & & & Process. & 1.000 & .606 \\
\hline & & & & & & Client_r & 1.000 & .785 \\
\hline & & & & & & People_r & 1.000 & .705 \\
\hline & & & & & & Society_r & 1.000 & .821 \\
\hline & & & & & & Key_r & 1.000 & .779 \\
\hline
\end{tabular}


Table 6. Factor analysis of the enabler group

\begin{tabular}{|c|c|c|c|c|c|c|c|c|}
\hline \multirow{2}{*}{ Factor } & \multicolumn{3}{|c|}{ Initial Eigen values } & \multicolumn{3}{|c|}{ Extraction Sums of Squared Loadings } & \multirow{2}{*}{ Criteria } & \multirow{2}{*}{$\frac{\text { Factor }}{1}$} \\
\hline & Total & $\%$ of Variance & Cumulative $\%$ & Total & $\%$ of Variance & Cumulative $\%$ & & \\
\hline 1 & 3.724 & 74.477 & 74.477 & 3.420 & 68.399 & 68.399 & Lead. & .878 \\
\hline 2 & .579 & 11.578 & 86.055 & & & & Strat. & .905 \\
\hline 3 & .371 & 7.417 & 93.473 & & & & Peop. & .828 \\
\hline 4 & .182 & 3.641 & 97.114 & & & & Partn. & .769 \\
\hline 5 & .144 & 2.886 & 100.000 & & & & Proces. & .743 \\
\hline
\end{tabular}

Table 7. Factor analysis of the result group

\begin{tabular}{|c|c|c|c|c|c|c|c|c|}
\hline \multirow{2}{*}{ Factor } & \multicolumn{3}{|c|}{ Initial Eigen values } & \multicolumn{3}{|c|}{ Extraction Sums of Squared Loadings } & \multirow{2}{*}{$\begin{array}{c}\text { Factor } \\
1\end{array}$} & \multirow{2}{*}{ Criteria } \\
\hline & Total & $\%$ of Variance & Cumulative $\%$ & Total & $\%$ of Variance & Cumulative $\%$ & & \\
\hline 1 & 2.445 & 61.133 & 61.133 & 1.935 & 48.387 & 48.387 & .676 & Client_r \\
\hline 2 & .886 & 22.156 & 83.290 & & & & .656 & People_r \\
\hline 3 & .368 & 9.200 & 92.490 & & & & .673 & Society_r \\
\hline 4 & .300 & 7.510 & 100.000 & & & & .771 & Key_r \\
\hline
\end{tabular}

Table 8 shows the factor analysis conducted on all of the criteria. It can be seen that, contrary to the Enablers and Results, two factors were extracted, with Eigen values of 5.724 and 1.017 for factors 1 and 2 respectively. This shows that all of the criteria together could not contribute together to one single construct, i.e. excellence. Communalities in the right hand column show that Society results (in black shading), Client results (to a lesser degree, grey shading) and Partnership criterion (in bold, Table 8) contribute to the second factor.

To confirm factor analysis we conducted ANOVA. The significance value of the F test, in Table 9, is 0.000 which validates these two groups as separate. Furthermore, Table 9 shows how the Enablers excellence con- tributes highly to the Results excellence, where $71.8 \%$ of the variability of the data is explained by the model. Figure 2 shows a scatter plot of the two excellence factors, which shows the strong and almost linear dependence.

The weights of the criteria have been shown to vary over the years without any real justification and therefore authors (Bassioni et al. 2005; Eskildsen, Dahlgaard 2000) have started to criticize the model for not corresponding to the way that companies are working. In order to define new weights, authors used various methods. E.g. Bassioni et al. (2004) and Eskildsen et al. (2000) used the factor regression coefficient; Cheng and Li (2001) used Analytic Hierarchy Process (AHP), etc. We used the factor regression coefficient to assess impact of each

Table 8. Factor analysis of all the criteria

\begin{tabular}{|c|c|c|c|c|c|c|c|c|c|}
\hline \multirow{2}{*}{ Component } & \multicolumn{3}{|c|}{ Initial Eigen values } & \multicolumn{3}{|c|}{ Extraction Sums of Squared Loadings } & \multicolumn{2}{|c|}{ Component } & \multirow{2}{*}{ Criteria } \\
\hline & Total & $\%$ of Variance & Cumulative $\%$ & Total & $\%$ of Variance & Cumulative $\%$ & 1 & 2 & \\
\hline 1 & 5.724 & 63.595 & 63.595 & 5.724 & 63.595 & 63.595 & .891 & -.098 & Lead. \\
\hline 2 & 1.017 & 11.304 & 74.899 & 1.017 & 11.304 & 74.899 & .900 & -.262 & Strat. \\
\hline 3 & .717 & 7.967 & 82.866 & & & & .845 & -.079 & Peop. \\
\hline 4 & .427 & 4.741 & 87.608 & & & & .800 & .047 & Partn. \\
\hline 5 & .403 & 4.473 & 92.081 & & & & .778 & -.020 & Proces. \\
\hline 6 & .310 & 3.449 & 95.530 & & & & .677 & .572 & Client_r \\
\hline 7 & .203 & 2.256 & 97.786 & & & & .767 & -.342 & People_r \\
\hline 8 & .123 & 1.372 & 99.157 & & & & .609 & .670 & Society_r \\
\hline 9 & .076 & .843 & 100.000 & & & & .862 & -.191 & Key_r \\
\hline
\end{tabular}

Note: Dark and grey cells note relatively evenly distributed communalities of the two components. The bold values indicate shared variance over two components.

Table 9. ANOVA for the Enablers and Results excellence factors

\begin{tabular}{ccccccccc}
\hline \multirow{2}{*}{$\mathrm{R}$} & \multirow{2}{*}{$\mathrm{R}^{2}$} & \multirow{2}{*}{$\begin{array}{c}\text { Adjusted } \mathrm{R}^{2} \\
\end{array}$} & & \multirow{2}{*}{$\begin{array}{c}\text { Std. Error of the } \\
\text { Estimate }\end{array}$} & \multicolumn{4}{c}{ Change Statistics } \\
\cline { 5 - 9 } & & & & $\mathrm{R}^{2}$ Change & F Change & df1 & df2 & Sig. F Change \\
\hline .853 & .727 & .718 & .51148017 & .727 & 85.142 & 1 & 32 & .000 \\
\hline
\end{tabular}




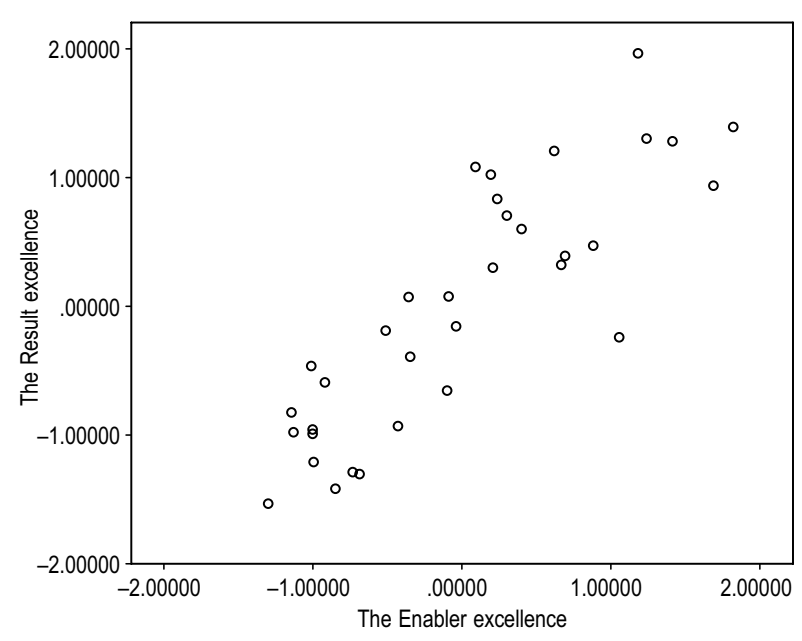

Fig. 2. Scatter plot of the Enablers and Results excellence factors

criterion on the latent factor "excellence". Because the factor analysis, we did this separately for the Enablers and Results.

The regression coefficients are shown in Table 10. Since score coefficients were not suitable for EFQM excellence scoring, we divided each criterion from the enabler group by the total of all coefficients and multiplied it by 500 . The same was done for the results.

Table 11 shows the correlations among each of the EFQM criteria. All the correlations were positive and significantly different from zero. The numbers in black shadings show values smaller than 0.5 . The correlations were calculated for every perspective and the scores were assigned to the model (this is shown in the following section).

\section{Findings and discussion}

\subsection{There is no latent factor common to all the model's criteria}

We found no latent factor "excellence" common to all the model's criteria. Yet we found two categories, the Enablers and Results, which contribute to the latent factor and should be considered separately, i.e. the Enablers and Results, are separately identifiable in the internal structure of the model and are presented as a latent factor that produces complementarities between their components. Therefore we accepted the first hypothesis and thus validated the model's original structure. The structure given in Figure 3, shows how the Enablers contribute to the Enabler excellence, where the arrow points from the Enablers to the Results group. Consequently the Results group leads to the Results excellence. Similar was found by Dijkstra (1997) but on the earlier version of the model (before 2003). Still these findings are contrary to some past studies which put all of the EFQM criteria together in direct relation with one single construct "excellence" (Bassioni et al. 2004).

Previous studies (Rahman, Bullock 2005; Rahman 2004; Yong, Wilkinson 2001; Cua et al. 2001) also dis-

Table 10. Component score coefficients and criterion weights

\begin{tabular}{|c|c|c|c|c|c|}
\hline & \multicolumn{2}{|c|}{ Enablers } & & \multicolumn{2}{|c|}{ Results } \\
\hline & Score coefficients & Criterion Weights & & Score coefficients & Criterion Weights \\
\hline Leadership & 0.911597 & 107 & Clients & 0.757445 & 122 \\
\hline Strategy & 0.939236 & 110 & People & 0.735359 & 118 \\
\hline People & 0.858961 & 100 & Society & 0.753898 & 121 \\
\hline $\begin{array}{l}\text { Partnership } \\
\text { \& Resources }\end{array}$ & 0.798286 & 93 & Key performance results & 0.864068 & 139 \\
\hline Processes & 0.770996 & 90 & & & \\
\hline Total & 4.279076 & 500 & Total & 3.110771 & 500 \\
\hline
\end{tabular}

Table 11. Example of the correlation matrix for the Investors' perspective

\begin{tabular}{|c|c|c|c|c|c|c|c|c|c|}
\hline Criteria & Leader. & Strat. & Peop. & Partner. & Proces. & Client_r & People_r & Society_r & Key_r \\
\hline Leader. & 1.000 & & & & & & & & \\
\hline Strat. & 0.521 & 1.000 & & & & & & & \\
\hline Peop. & 0.754 & 0.658 & 1.000 & & & & & & \\
\hline Partner. & 0.460 & 0.511 & 0.563 & 1.000 & & & & & \\
\hline Proces. & 0.521 & 0.947 & 0.794 & 0.635 & 1.000 & & & & \\
\hline Client_r & 0.286 & 0.274 & 0.707 & 0.309 & 0.443 & 1.000 & & & \\
\hline People_r & 0.613 & 0.551 & 0.549 & 0.389 & 0.448 & 0.181 & 1.000 & & \\
\hline Society_r & 0.365 & 0.040 & 0.680 & 0.184 & 0.235 & 0.935 & 0.130 & 1.000 & \\
\hline Key_r & 0.754 & 0.884 & 0.746 & 0.531 & 0.830 & 0.472 & 0.621 & 0.310 & 1.000 \\
\hline
\end{tabular}

Note: the numbers in black shadings show lower correlations. 


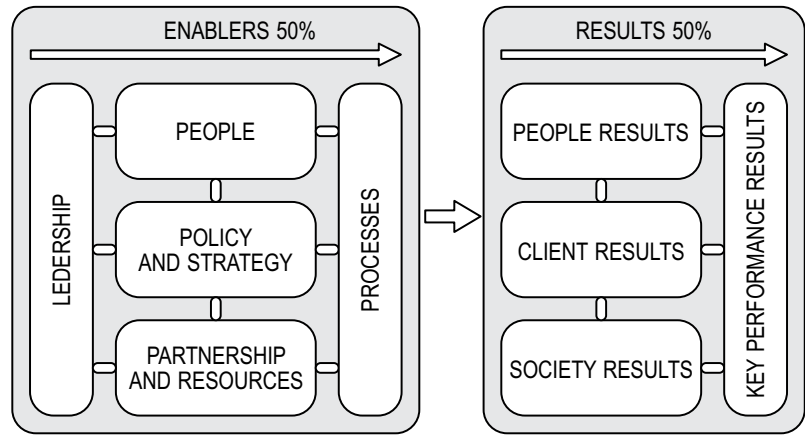

Fig. 3. The excellence model validated by the factor analysis

tinguished between social and technical dimensions represented in the enabler and results, which shows how the holistic approach of TQM is represented in EFQM. We found a strong relationship between the Enablers and Results, as the excellence construct is explained by almost $75 \%$ variability of the enablers and $61 \%$ variability of the results. This confirms the results obtained by Calvo-Mora et al. (2005) and Reiner (2002) regarding the internal logic between the EFQM elements. Moreover, this high relationship between the two groups supports the TQM principles and numerous studies (Belohlav 1993; Flynn et al. 1994; Train, Williams 2000) which show the importance of adopting a holistic view of the model. This means that there is a difference between the Enablers and Results criteria in the degree to which they contribute to excellence which supports the first hypothesis.

\subsection{The Excellence model in its present form is not fully applicable for every management perspective in the construction industry, but only for the contractor perspective}

Up to now there have been few studies dealing with validation of EFQM in the construction industry, and none that validated the model on real assessment data. As explained in the methodology part, the South European (SEE) construction industry has a specific business culture. SEE countries have strict law regulation that defines project stakeholders. There are three main management perspectives: investors (sponsors, developers), consultants (project managers, designers, architects, supervision, etc.) and contractors. Therefore these perspectives were analyzed separately. The correlation coefficients from Table were used to validate the relationships of the criteria. Figures 4-7 show the correlation coefficients for every perspective separately.

It can be seen that only the Contractor perspective (Fig. 7) corresponds with the theoretical presumptions of EFQM. When looking at all the perspectives (Fig. 4), a weaker relationship was identified between the Client and People results. The investor perspective (Fig. 5) showed a weaker relationship between Client and People results and between Society, Processes and Key performance results. This was also supported by factor analysis, which showed that, when analyzing all the criteria,

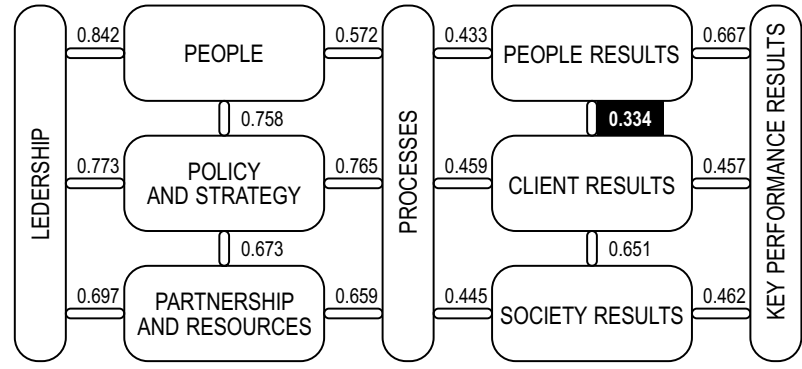

Fig. 4. Correlation coefficients for all the perspectives

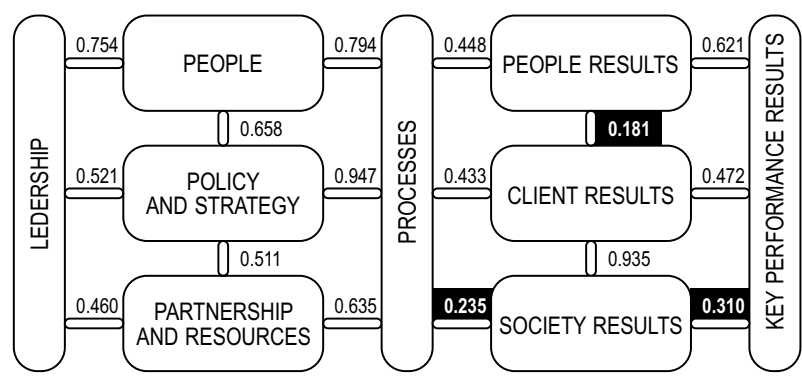

Fig. 5. Correlation coefficients for the investors

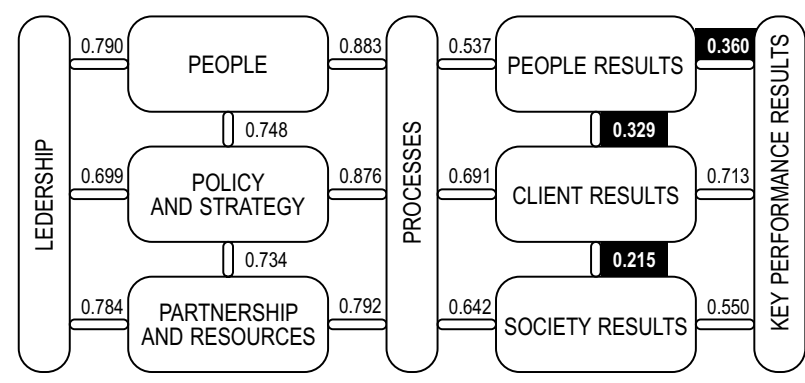

Fig. 6. Correlation coefficients for the consultants Note: the numbers in black shadings show lower correlations between the criteria.

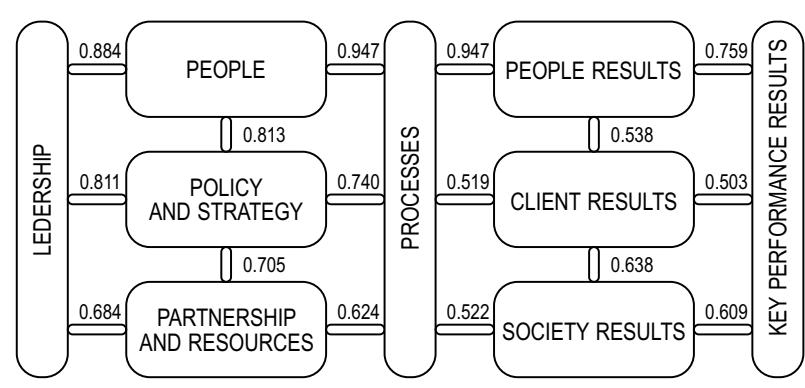

Fig. 7. Correlation coefficients for the contractors

the Society criterion does not contribute to an excellence construct. The same was noticed by Gomez et al. (2011), but not Reiner (2002) who noticed positive correlation of the People and the Client results. The Society criterion was also reported by other authors by (Bou-Llusar et al. 2009; Lee et al. 2003; Ghosh et al. 2003; Gomez et al. 2011) as not being compatible with the Enablers. The consultant perspective (Fig. 6) showed a weaker link among People results, Client results and Society re- 
sults and between People results and Key Performance results. Again, the Society criterion had a weaker link, which supports the aforementioned notions. Therefore, while the enabler criteria are aligned with EFQM's original structure, the results group raises certain doubts. All these findings rejected the second hypothesis and showed that the EFQM model is not applicable for every management perspective in the construction industry.

\subsection{The original EFQM weights do not correspond with the construction industry}

Figure 8 shows EFQM model with updated criteria weights (based on the regression coefficients from Table 10), which show how the construction industry obtains excellence. The main benefit of this model is that it provides a model tailored particularly for the construction industry and especially for the contractor perspective. Figure 8 shows that the model puts less emphasis on the Processes and Client results and more emphasis on the Policy and Strategy, People, People results and Society results. These results rejected the third hypothesis and showed that the original EFQM weights are not properly aligned with the construction industry.

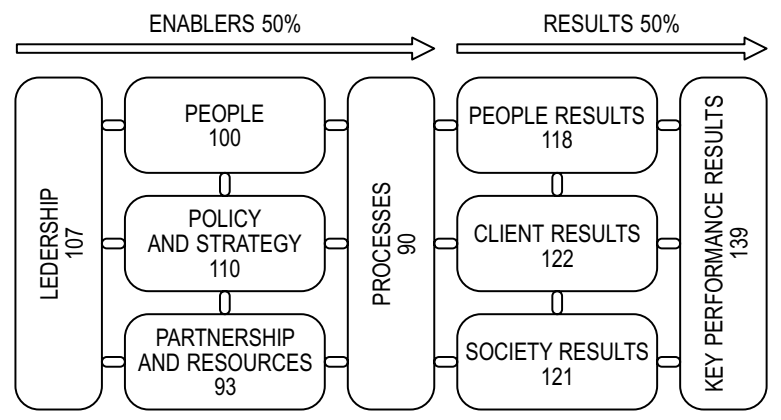

Fig. 8. New weights for the EFQM model's use in the construction industry

\section{Conclusions}

This paper explored the internal structure of the EFQM Excellence model and has validated the model's theoretical presumptions. This was done using the real assessment data, obtained from assessing the companies using EFQM self-assessment sheets. This is the first study that uses this kind of data and offers a more precise evaluation of how the EFQM model functions. We have found that effective EFQM implementation requires an approach that manages the Enabler and Result criteria separately. Furthermore, the results show that the original EFQM model, does not work on the principle "one size fits all". This does not mean that the elements of the model cannot be useful to organizations, but certain relationships of the model do not work as the model suggests.

The main findings are: 1 . There is an enabler excellence construct that underlines the level of deployment obtained by each enabler criteria; 2 . There is a result excellence construct that underlines the level of deployment obtained by each result criteria; 3 . The weights, set by the original model, do not entirely correspond with the way the construction industry attains excellence; 4 . The EFQM model, in its present form is only suitable for contractor type organizations and thus further improvements are required for Consultants' and Investors' type organizations. This led us to conclude that EFQM is a suitable award model and a framework for implementing TQM in the construction industry.

From the methodological point of view, we adopted a global methodology for testing award models, which has already been proven on similar studies (Bou-Llusar et al. 2009; Curkovic et al. 2000; Dijkstra 1997). However, this study extends to correlations among the criteria within different management perspectives. Furthermore, our approach is in accordance with Dijkstra (1997), Winn and Cameron (1998), Wilson and Collier (2000) and Bou-Llusar et al. (2009), who found a latent factor that underlines the model's criteria and the existence of causal relationship between award criteria.

The results of this study could be very interesting for managers in pursuit of winning a quality award, i.e. the EFQM Excellence Award, because they can serve as a guide for conducting EFQM self-assessment and implementing TQM for the first time. Furthermore, we propose an alternative model for the construction organizations, especially useful for the contractor perspective. Moreover, the analysis of the relationships amongst the model criteria can help organizations in defining priorities for further improvement. Only by understanding the structure of the model and linkages between the elements can allow organizations to benefit fully from the self-assessment process.

However, this study has certain limitations, which need to be addressed. The sample was a convenience sample, made of companies willing to participate in the research (among 142 larger and medium-sized companies, we covered 34 organizations). However, this was the first time that the real assessment data were collected from the construction industry, which provides the importance to this study. Second, since the construction is largely a project-oriented industry, this model might not be successfully applicable to other production-oriented industries. Therefore companies from other industries, besides the construction, are encouraged and welcome to use the new weights, but with the rider that they were designed specifically for the contractors and project oriented companies. Furthermore, companies using these new weights might have issues when benchmarking against the original EFQM model.

The EFQM model is obviously not an ideal model. We agree with Gomez et al. (2011) that the problem can come from two sources: the assumptions of the original model or the way the evaluators interpret the model. Therefore the options for further research are wide. First, a natural extension of this study would be to focus on finding the weights for the other two perspectives. Figu- 
res 4-7 show that among Investors and Consultants few links are highly correlated, e.g. Client results and Society results for the Investors' perspective. This confirms that there is quite a bit of shared variance within these two perspectives, which shows the need for more validation on a larger sample. Still, the Investors and Consultants can use the model, but with a proviso regarding the areas shaded on the Figures 5 and 6. Second, in order to solve the benchmarking problem regarding the new weights, an analysis of the differences in EFQM between different industries would be necessary. Furthermore, ascertain authors suggested (Prasad, Tata 2003; Rungtusanatham et al. 2005; Flynn et al. 1994; Bou-Llusar et al. 2009), analysing the differences in different approaches between countries in the EFQM model would be necessary.

Finally, we strongly call for further research in this unexplored direction to derive even better total quality management model for the construction.

\section{References}

Adair, C.; Simpson, L.; Birdsell, J.; Omelchuk, K.; Casebeer, A.; Gardiner, H.; Newman, S.; Beckie, A.; Clelland, S.; Hayden, K. 2003. Performance measurement systems in health and mental health services: models, practices and effectiveness. A State of the Science Review. Submitted to the Alberta Heritage Foundation for Medical Research, USA. 187 p.

Adams, G.; McQueen, G.; Seawright, K. 1999. Revisiting the stock price impact of quality awards, Omega 27(6): 595 604. http://dx.doi.org/10.1016/S0305-0483(99)00025-0

Ahire, S. L.; Golhar, D. Y.; Waller, M. A. 1996. Development and validation of TQM implementation constructs, Decision Sciences 27(1): 23-56. http://dx.doi.org/10.1111/j.1540-5915.1996.tb00842.x

Ahmad, I. U.; Sein, M. K. 1997. Construction project teams for TQM: a factor-element impact model, Construction Management and Economics 15(5): 457-467. http://dx.doi.org/10.1080/014461997372827

Andersen, H.; Lawrie, G.; Shulver, M. 2000. The balanced scorecard vs. the EFQM business excellence model: which is the better strategic management tool?. 2GC Limited. Presentation made to the 9th Turkish Quality Congress, November, 2000, Istambul, Turkey.

Askey, J.; Dale, B. 1994. From ISO 9000 series registration to total quality management: an examination, Quality Management Journal 1(4): 67-76.

Bassioni, H.; Price, A.; Hassan, T. 2004. Performance measurement in construction, Journal of Management in Engineering 20(2): 42-50.

http://dx.doi.org/10.1061/(ASCE)0742-597X(2004)20:2(42)

Bassioni, H.; Price, A.; Hassan, T. 2005. Building a conceptual framework for measuring business performance in construction: an empirical evaluation, Construction Management and Economics 23(5): 495-507. http://dx.doi.org/10.1080/0144619042000301401

Bassioni, H.; Hassan, T.; Price, A. 2008. Evaluation and analysis of criteria and sub-criteria of a construction excellence model, Engineering, Construction and Architectural Management 15(1): 21-41. http://dx.doi.org/10.1108/09699980810842043

Bayo-Moriones, A.; Merino-Díaz de Cerio, J. 2001. Quality management and high performance work practices: do they coexist?, International Journal of Production Economics 73(3): 251-259.

http://dx.doi.org/10.1016/S0925-5273(01)00089-5
Bayo-Moriones, A.; Merino-Díaz-de-Cerio, J.; Antonio Escamilla-de-León, S.; Mary Selvam, R. 2011. The impact of ISO 9000 and EFQM on the use of flexible work practices, International Journal of Production Economics 130(1): 33-42. http://dx.doi.org/10.1016/j.ijpe.2010.10.012

Beatham, S.; Anumba, C.; Thorpe, T.; Hedges, I. 2004. KPIs: a critical appraisal of their use in construction, Benchmarking: An International Journal 11(1): 93-117.

Belohlav, J. A. 1993. Quality, strategy, and competitiveness, California Management Review, Spring 1993, 55-81. http://dx.doi.org/10.2307/41166743

Bou-Llusar, J. C.; Escrig-Tena, A. B.; Roca-Puig, V.; BeltránMartín, I. 2009. An empirical assessment of the EFQM Excellence Model: evaluation as a TQM framework relative to the MBNQA Model, Journal of Operations Management 27(1): 1-22. http://dx.doi.org/10.1016/j.jom.2008.04.001

Bourne, M.; Neely, A.; Mills, J.; Platts, K. 2003. Implementing performance measurement systems: a literature review, International Journal of Business Performance Management 5(1): 1-24. http://dx.doi.org/10.1504/IJBPM.2003.002097

Brewerton, P.; Millward, L. 2001. Organizational research methods: a guide for students and researchers. London: Sage Publications Ltd. $224 \mathrm{p}$.

Calvo-Mora, A.; Leal, A.; Roldán, J. L. 2005. Relationships between the EFQM model criteria: a study in Spanish universities, Total Quality Management \& Business Excellence 16(6): 741-770. http://dx.doi.org/10.1080/14783360500077708

Cheng, E. W. L.; Li, H. 2001. Analytic hierarchy process: an approach to determine measures for business performance, Measuring Business Excellence 5(3): 30-37. http://dx.doi.org/10.1108/EUM0000000005864

Codling, S. 1995. Best practice benchmarking. Gower Brookfield, Vt., USA. 153 p.

Cooper, D. R.; Emory, W. 1995. Business research methods. McGraw-Hill/Irwin Series in Operations and Decision Sciences. McGraw-Hill, USA. 784 p.

Corredor, P.; Go, S. 2011. TQM and performance: is the relationship so obvious?, Journal of Business Research 64(8): 830-838. http://dx.doi.org/10.1016/j.jbusres.2010.10.002

Costello, A. B.; Osborne, J. W. 2005. Best practices in exploratory factor analysis: four recommendations for getting the most from your analysis, Practical Assessment, Research \& Evaluation 10(7): 1-9.

Crosby, P. B. 1979. Quality is free: the art of making quality certain: how to manage quality - so that it becomes a source of profit for your business. McGraw-Hill, USA. $309 \mathrm{p}$.

Cua, K. O.; McKone, K. E.; Schroeder, R. G. 2001. Relationships between implementation of TQM, JIT, and TPM and manufacturing performance, Journal of Operations Management 19(6): 675-694. http://dx.doi.org/10.1016/S0272-6963(01)00066-3

Curkovic, S.; Melnyk, S.; Calantone, R.; Handfield, R. 2000. Validating the Malcolm Baldrige National Quality Award framework through structural equation modelling, International Journal of Production Research 38(4): 765-791. http://dx.doi.org/10.1080/002075400189149

de Leeuw, S.; van den Berg, J. P. 2011. Improving operational performance by influencing shopfloor behavior via performance management practices, Journal of Operations Management 29(3): 224-235. http://dx.doi.org/10.1016/j.jom.2010.12.009

de Waal, A. 2008. The secret of high performance organizations, Management Online Review [online], [cited 10 October 2012]. Available from Internet: http://www.hpocent- 
er.nl/uploads/MORE\%20-\%20The $\% 20$ Secret $\% 20$ of $\% 20$ HPOs\%20-\%20April2008.pdf

Deming, W. 1982. Quality, productivity, and competitive position. Massachusetts: Massachusetts Institute of Technology, Center for Advanced Engineering Study, USA. 373 p.

Dijkstra, L. 1997. An empirical interpretation of the EFQM framework, European Journal of Work and Organizational Psychology 6(3): 321-341. http://dx.doi.org/10.1080/135943297399097

EFQM 2005. Radarise your business for success. Brussels: EFQM Publishing. $274 \mathrm{p}$.

El-Mashaleh, M.; Minchin, Jr. R.; O’Brien, W. 2007. Management of construction firm performance using benchmarking, Journal of Management in Engineering 23(1): 10-18. http://dx.doi.org/10.1061/(ASCE)0742-597X(2007)23:1(10)

Eskildsen, J. K. 1998. Identifying the vital few using the European Foundation for Quality Management model, Total Quality Management \& Business Excellence 9(4): 92-94.

Eskildsen, J. K.; Dahlgaard, J. J. 2000. A causal model for employee satisfaction, Total Quality Management \& Business Excellence 11(8): 1081-1094. http://dx.doi.org/10.1080/095441200440340

Eskildsen, J. K.; Kristensen, K.; Juhl, H. J. 2000. The causal structure of the EFQM excellence model, in Proc. of the 1st International Research Conference on Organizational Excellence in the Third Millennium, August, 2000, Colorado, USA. 8 p.

Flynn, B. B.; Schroeder, R. G.; Sakakibara, S. 1994. A framework for quality management research and an associated measurement instrument, Journal of Operations Management 11(4): 339-366. http://dx.doi.org/10.1016/S0272-6963(97)90004-8

Forza, C.; Filippini, R. 1998. TQM impact on quality conformance and customer satisfaction: a causal model, International Journal of Production Economics 55(1): 1-20. http://dx.doi.org/10.1016/S0925-5273(98)00007-3

Ghosh, S.; Handfield, R. B.; Kannan, V. R.; Tan, K. C. 2003. A structural model analysis of the Malcolm Baldrige National Quality Award framework, International Journal of Management and Decision Making 4(4): 289-311. http://dx.doi.org/10.1504/IJMDM.2003.003996

Gomez, J. G.; Costa, M. M.; Lorente, A. R. M. 2011. A critical evaluation of the EFQM model, International Journal of Quality \& Reliability Management 28(5): 484-502. http://dx.doi.org/10.1108/02656711111132544

Grandzol, J. R.; Gershon, M. 1998. A survey instrument for standardizing TQM modeling research, International Journal of Quality Science 3(1): 80-105. http://dx.doi.org/10.1108/13598539810203887

Gryna, F. M.; Juran, J. M. 2001. Quality planning and analysis: from product development through use. McGraw-Hill Science/Engineering/Math, USA. 672 p.

Hendricks, K. B.; Singhal, V. R. 1996. Quality awards and the market value of the firm: an empirical investigation, Management Science 42(3): 415-436. http://dx.doi.org/10.1287/mnsc.42.3.415

Henson, R. K.; Roberts, J. K. 2006. Use of exploratory factor analysis in published research, Educational and Psychological Measurement 66(3): 393-416. http://dx.doi.org/10.1177/0013164405282485

Hillman, G. 1994. Making self-assessment successful, The TQM Magazine 6(3): 29-31. http://dx.doi.org/10.1108/09544789410057863

Junnonen, J. 1998. Strategy formation in construction firms, Engineering, Construction and Architectural Management 5(2): 107-114. http://dx.doi.org/10.1108/eb021065

Kaplan, R.; Norton, D. 1992. The balanced scorecard: measures that drive performance, Harvard Business Review 70(1): 71-79.
Kartha, C. 2004. A comparison of ISO 9000: 2000 quality system standards, QS9000, ISO/TS 16949 and Baldrige criteria, The TQM Magazine 16(5): 331-340. http://dx.doi.org/10.1108/09544780410551269

Kennerley, M.; Neely, A. 2002. A framework of the factors affecting the evolution of performance measurement systems, International Journal of Operations and Production Management 22(11): 1222-1245. http://dx.doi.org/10.1108/01443570210450293

Lam, E.; Chan, A.; Chan, D. 2004. Benchmarking design-build procurement systems in construction, Benchmarking: an International Journal 11(3): 287-302.

Lee, S.; Rho, B. H.; Lee, S. G. 2003. Impact of Malcolm Baldrige National Quality Award criteria on organizational quality performance, International Journal of Production Research 41(9): 2003-2020. http://dx.doi.org/10.1080/0020754031000077329

Lingard, H. C.; Rowlinson, S. 2006. Sample size in factor analysis: why size matters. Hong Kong: University of Hong Kong. 6 p.

MacCallum, R. C.; Widaman, K. F.; Preacher, K. J.; Hong, S. 2001. Sample size in factor analysis: the role of model error, Multivariate Behavioral Research 36(4): 611-637. http://dx.doi.org/10.1207/S15327906MBR3604_06

Marzuki, P. F.; Permadi, H.; Sunaryo, I. 2012. Factors affecting job satisfaction of workers in Indonesian construction companies, Journal of Civil Engineering and Management 18(3): 299-309. http://dx.doi.org/10.3846/13923730.2012.698889

McAdam, R.; Leonard, D. 2005. A TQM dynamics perspective on Baldrige and business excellence model comparisons, Total Quality Management \& Business Excellence 16(6): 771-791. http://dx.doi.org/10.1080/14783360500077757

McCabe, S. 2001. Benchmarking in construction. Chichester: Blackwell Publishing. 291 p. http://dx.doi.org/10.1002/9780470696057

Neely, A. 2002. Business performance measurement: theory and practice. Cambridge: Cambridge University Press. 369 p. http://dx.doi.org/10.1017/CBO9780511753695

Niven, P. 2006. Balanced scorecard step-by-step: maximizing performance and maintaining results. Chichester: Wiley. $327 \mathrm{p}$.

Nudurupati, S. S.; Bititci, U. S.; Kumar, V.; Chan, F. T. S. 2010. State of the art literature review on performance measurement, Computers \& Industrial Engineering 60(2): 279290. http://dx.doi.org/10.1016/j.cie.2010.11.010

Prabhu, V.; Appleby, A.; Yarrow, D. 2000. The impact of ISO 9000 and TQM on best practice/performance, The TQM Magazine 12(2): 84-92. http://dx.doi.org/10.1108/09544780010318334

Prasad, S.; Tata, J. 2003. The role of socio-cultural, politicallegal, economic, and educational dimensions in quality management, International Journal of Operations \& Production Management 23(5): 487-521. http://dx.doi.org/10.1108/01443570310471839

Qureshi, T. M.; Warraich, A. S.; Hijazi, S. T. 2009. Significance of project management performance assessment (PMPA) model, International Journal of Project Management 27(4): 378-388.

http://dx.doi.org/10.1016/j.ijproman.2008.05.001

Radujkovic, M.; Vukomanovic, M.; Dunovic, I. B. 2010. Application of key performance indicators in South Eastern European construction, Journal of Civil Engineering and Management 16(4): 521-530. http://dx.doi.org/10.3846/jcem.2010.58

Rahman, S. 2004. The future of TQM is past. Can TQM be resurrected?, Total Quality Management \& Business Excellence 15(4): 411-422. http://dx.doi.org/10.1080/1478336042000183550 
Rahman, S.; Bullock, P. 2005. Soft TQM, hard TQM, and organisational performance relationships: an empirical investigation, Omega 33(1): 73-83. http://dx.doi.org/10.1016/j.omega.2004.03.008

Reiner, G. 2002. Analysis of critical factors of company success based on the EFQM Excellence model, in Proc. of the 7th World Congress for Total Quality Management, 2002, Verona, Italy, Vol: 2, 361-366.

Ritchie, L.; Dale, B. 2000. Self-assessment using the business excellence model: a study of practice and process, International Journal of Production Economics 66(3): 241254. http://dx.doi.org/10.1016/S0925-5273(99)00130-9

Robinson, H.; Anumba, C.; Carrillo, P.; Al-Ghassani, A. 2004. Business performance measurement practices in construction engineering organizations, Measuring Business Excellence 9(1): 13-22. http://dx.doi.org/10.1108/13683040510588800

Rungtusanatham, M.; Forza, C.; Koka, B.; Salvador, F.; Nie, W. 2005. TQM across multiple countries: Convergence Hypothesis versus National Specificity arguments, Journal of Operations Management 23(1): 43-63. http://dx.doi.org/10.1016/j.jom.2004.10.002

Rusjan, B. 2005. Usefulness of the EFQM excellence model: Theoretical explanation of some conceptual and methodological issues, Total Quality Management \& Business Excellence 16(3): 363-380. http://dx.doi.org/10.1080/14783360500053972

Sharif, A. M. 2002. Benchmarking performance management systems, Benchmarking: An International Journal 9(1): 62-85.

Sila, I.; Ebrahimpour, M. 2002. An investigation of the total quality management survey based research published between 1989 and 2000: a literature review, International Journal of Quality \& Reliability Management 19(7): 902970. http://dx.doi.org/10.1108/02656710210434801

Stockdale, D. 1998. Can total quality management 'add value' in construction?, Construction Manager 4(2): 22-23.

Tari, J. J.; Molina, J. F.; Castejon, J. L. 2007. The relationship between quality management practices and their effects on quality outcomes, European Journal of Operational Research 183(2): 483-501.

http://dx.doi.org/10.1016/j.ejor.2006.10.016
Tchidi, M. F.; He, Z.; Li, Y. B. 2012. Process and quality improvement using Six Sigma in construction industry, Journal of Civil Engineering and Management 18(2): 158172. http://dx.doi.org/10.3846/13923730.2012.657411

Train, L.; Williams, C. 2000. Evolution of quality management: British benefit enquiry line, International Journal of Public Sector Management 13(6): 526-539. http://dx.doi.org/10.1108/09513550010356737

Tummala, V. M. R.; Tang, C. 1996. Strategic quality management, Malcolm Baldrige and European quality awards and ISO 9000 certification: core concepts and comparative analysis, International Journal of Quality \& Reliability Management 13(4): 8-38. http://dx.doi.org/10.1108/02656719610114371

Van der Wiele, A.; Williams, A.; Dale, B. 2000. ISO 9000 series registration to business excellence: the migratory path, Business Process Management Journal 6(5): 417-427. http://dx.doi.org/10.1108/14637150010353911

Watson, P.; Seng, L. 2002. Implementing the European foundation for quality management model in construction, in Proc. of FIG 22 2 International Congress, 19-26 April, 2002, Washington, D.C. USA. 18 p.

Westerveld, E. 2003. The Project Excellence Modelź: linking success criteria and critical success factors, International Journal of Project Management 21(6): 411-418. http://dx.doi.org/10.1016/S0263-7863(02)00112-6

Wilson, D. D.; Collier, D. A. 2000. An empirical investigation of the Malcolm Baldrige National Quality Award causal model, Decision Sciences 31(2): 361-383. http://dx.doi.org/10.1111/j.1540-5915.2000.tb01627.x

Winn, B. A.; Cameron, K. S. 1998. Organizational quality: an examination of the Malcolm Baldrige National quality framework, Research in Higher Education 39(5): 491512. http://dx.doi.org/10.1023/A:1018745505108

Yong, J.; Wilkinson, A. 2001. Rethinking total quality management, Total Quality Management \& Business Excellence 12(2): 247-258. http://dx.doi.org/10.1080/09544120120011460

Yusof, S. R. M.; Aspinwall, E. 2000. Total quality management implementation frameworks: comparison and review, Total Quality Management \& Business Excellence 11(3): 281-294. http://dx.doi.org/10.1080/0954412006801

Mladen VUKOMANOVIC. PhD, an Assistant Professor at the Faculty of Civil Engineering of the University of Zagreb. He leads an IT project for construction management and a research project "Business Excellence in the Construction Industry in Croatia". He is the Managing Editor of the international scientific journal: Organization, Technology \& Management in Construction. His research interests are: performance management, key performance indicators, benchmarking, TQM, strategic management in construction, project management processes and information technology in construction.

Mladen RADUJKOVIC. PhD, a full time Professor at the Faculty of Civil Engineering of the University of Zagreb, Editor-in-chief of the international scientific journal: Organization, Technology \& Management in Construction, President of the Croatian Association for Project Management and President of IPMA. He leads the research project "Risk and change management in the project oriented construction business". His research interests are: project management, risk management, management control systems, scheduling techniques in construction management, change management and operational research.

Maja Marija NAHOD. MSc, a research and teaching assistant at the Faculty of Civil Engineering of the University of Zagreb. Besides working at the faculty, she holds the function of secretary of the Croatian Association for Project Management (IPMA member). Her research interests are: change management, operational research, risk management, construction management and project management. 